\title{
ANALISIS KESALAHAN PENYELESAIAN \\ SOAL BANGUN RUANG SISI LENGKUNG SISWA KELAS IX SMP NEGERI 5 KOTA TASIKMALAYA
}

\author{
Ida Nuraida \\ Pendidikan Matematika, FKIP, Universitas Galuh Ciamis \\ e-mail: ida.nuraidamath@gmail.com
}

\begin{abstract}
ABSTRAK
Materi bangun ruang sisi lengkung yang mencakup bangun ruang tabung, kerucut, dan bola, merupakan materi geometri yang kurang begitu disukai oleh siswa. Materi tersebut dianggap materi yang sulit untuk dipahami, sehingga siswa membuat kesalahan dalam menjawab soal yang berkaitan dengan materi tersebut. Tujuan penelitian ini adalah untuk mengidentifikasi jenis kesalahan-kesalahan yang dilakukan siswa dan mengetahui faktor-faktor yang menyebabkan kesalahan siswa dalam menjawab soal materi bangun ruang sisi lengkung. Metode penelitian yang digunakan yaitu penelitian deskriptif yang bersifat kualitatif. Pengumpulan data dalam penelitian ini adalah dengan metode dokumentasi, metode tes, dan metode wawancara.
\end{abstract}

Kata Kunci: Analisis kesalahan, 


\section{PENDAHULUAN}

Usaha untuk meningkatkan kualitas proses dan hasil pendidikan sudah selayaknya lebih diperhatikan, karena melalui pendidikan diyakini akan dapat mendorong dan memaksimalkan potensi siswa sebagai calon SDM yang handal untuk dapat bersikap dan berprilaku kritis, kreatif, logis dan inovatif dalam menghadapi serta menyelesaikan setiap permasalahan. Sejalan dengan itu Kurikulum Tingkat Satuan Pendidikan (Depdiknas: 2006) menyatakan tujuan pendidikan matematika adalah kecakapan atau kemahiran matematika yang diharapkan dapat tercapai oleh siswa dalam belajar matematika mulai dari SD, SMP sampai SMA adalah sebagai berikut; (1) pemahaman konsep; (2) penalaran; (3) komunikasi; (4) pemecahan masalah; (5) dan memiliki sikap menghargai kegunaaan matematika dalam kehidupan.

Berkenaan dengan peran matematika dalam kemajuan zaman, Levvit (dalam Buchori, 2000) menyatakan bahwa jika suatu masyarakat dibiarkan dalam kebutaan matematika maka akan membuat masyarakat tersebut kehilangan kemampuan untuk berpikir secara disipliner dalam menghadapi masalah-masalah nyata, yang dimulai dari masalah-masalah yang relatif sederhana hingga masalah-masalah yang benar-benar rumit.

Senada dengan hal itu maka berdasarkan pendapat Turmudi (2009) “... penguasaan mata pelajaran matematika memudahkan peserta didik untuk melatih berpikir logis, analitis, sistematis, kritis, dan inovatif yang difungsikan untuk mendukung pembentukan kompetensi program keahlian", maka dengan diberikannya mata pelajaran matematika terhadap peserta didik diharapkan mereka dapat mengikuti perkembangan jaman yang semakin canggih dengan teknologiteknologinya yang hampir merusak karakter dan kepribadian peserta didik.

Turmudi ( 2008 ) mengemukakan bahwa pembelajaran matematika selama ini hanya disampaikan kepada siswa secara informatif, artinya siswa hanya memperoleh informasi dari guru saja sehingga derajat kemelekatannya juga dapat dikatakan rendah.
Siswa sebagai subjek belajar kurang dilibatkan dalam menemukan konsep-konsep pelajaran yang harus dikuasainya. Hal ini menyebabkan konsep-konsep yang diberikan tidak membekas dalam ingatan siswa sehingga siswa merasa mudah lupa dan selalu kebingungan apabila mendapatkan soal yang diberikan guru.

Selain memberikan pembelajaran dengan melibatkan siswa, sebagai guru harus bijak dalam melihat fenomena yang terjadi, kenapa prestasi siswa selalu rendah. Penyebab rendahnya kualitas pembelajaran diantaranya yaitu kesalahan apa yang dilakukan siswa dalam menjawab persoalan matematika. Soedjadi (2000) mengklasifikasikan kesalahan-kesalahan yang sering dilakukan siswa yaitu: 1) kesalahan prosedural yaitu kesalahan dalam menggunakan algoritma (prosedur pekerjaan), misalnya kesalahan melakukan operasi hitung ; 2) kesalahan dalam mengorganisasikan data, misalnya kesalahan menuliskan apa yang diketahui, apa yang ditanyakan dari suatu soal; 3) kesalahan mengurutkan, mengelompokkan dan menyajikan data; 4) kesalahan dalam pemanfaatan simbol, tabel, dan grafik yang memuat suatu informasi; 5) kesalahan dalam melakukan manipulasi secara matematis, sifat-sifat dalam menyelesaikan soal; 6) kesalahan dalam menarik kesimpulan, misalnya kesalahan dalam menuliskan kesimpulan dari persoalan yang telah mereka kerjakan.

Berdasarkan hal tersebut, peneliti mengambil jenis kesalahan disesuaikan dengan materi yang diambil yaitu materi bangun ruang sisi lengkung.

\section{METODE PENELITIAN}

Metode yang digunakan dalam penelitian ini adalah Metode penelitian deskriptif yang bersifat kualitatif. Data penelitian ini berupa hasil jawaban tes siswa yang berbentuk uraian dan hasil wawancara siswa dengan guru. Subjek penelitian ini yaitu kelas IX SMP Negeri 5 Kota Tasikmalaya yang terdiri dari 34 siswa yang dianggap dapat memberikan informasi terkait dengan kesalahan dalam menjawab soal-soal bangun 
ruang sisi lengkung yang diteskan. Instrumen tes yang diberikan kepada siswa tersebut memuat 4 soal bangun ruang sisi lengkung.

Adapun rumus yang digunakan untuk menentukan persentase jenis kesalahan siswa menurut Soedjadi (2000) adalah sebagai berikut: $P=\frac{n}{N} \times 100 \%$
Keterangan:

$P=$ persentase masing - masing jenis kesalahan siswa

$n=$ banyaknya kesalahan untuk masingmasing jenis kesalahan

$N=$ banyaknya kemungkinan kesalahan

Tabel 1

Klasifikasi Persentase Banyaknya Kesalahan

\begin{tabular}{cc}
\hline Persentase & Kategori \\
\hline$P \geq 55 \%$ & Sangat tinggi \\
\hline $40 \% \leq P<55 \%$ & Tinggi \\
\hline $25 \% \leq P<40 \%$ & Cukup tinggi \\
\hline $10 \% \leq P<25 \%$ & Kecil \\
\hline$P<10 \%$ & Sangat kecil \\
\hline
\end{tabular}

HASIL PENELITIAN DAN PEMBAHASAN

Penelitian dilaksanakan di SMP Negeri 5 Kota Tasikmalaya kelas IX-H yang berjumlah 34 orang siswa. Penelitian diawali dengan pemberian tes soal berbentuk uraian yang berjumlah 4 butir soal dan selanjutnya diadakan wawancara terhadap 14 orang siswa yang melakukan jenis kesalahan yang berbeda. Berikut disajikan tabel hasil tes siswa untuk mengetahui kesalahan siswa pada soal bangun ruang sisi lengkung.

Tabel 2

Data Hasil Tes terhadap Kesalahan Siswa

\begin{tabular}{|c|c|c|c|c|c|c|}
\hline \multirow{2}{*}{ Jenis Kesalahan } & \multicolumn{4}{|c|}{ Butir Soal } & \multirow[t]{2}{*}{ Jml } & \multirow[t]{2}{*}{ Persentase Kesalahan } \\
\hline & 1 & 2 & 3 & 4 & & \\
\hline Prosedural & 3 & 3 & 4 & 3 & 13 & $10,8 \%$ \\
\hline Mengorganisasikan Data & 2 & 2 & 3 & 4 & 11 & $9,17 \%$ \\
\hline Mengurutkan & 2 & 3 & 2 & 5 & 12 & $10 \%$ \\
\hline Pemanfaatan simbol & 2 & 1 & 3 & 3 & 9 & $7,5 \%$ \\
\hline $\begin{array}{l}\text { Melakukan manipulasi } \\
\text { secara matematis }\end{array}$ & 3 & 4 & 3 & 7 & 17 & $14,2 \%$ \\
\hline Menarik kesimpulan & 2 & 3 & 3 & 4 & 12 & $10 \%$ \\
\hline Jumlah & 14 & 16 & 18 & 26 & & \\
\hline Persentase & $41,2 \%$ & $47 \%$ & $52,9 \%$ & $76,5 \%$ & & \\
\hline
\end{tabular}

Berdasarkan data dalam tabel 2, dapat diketahui bahwa siswa membuat kesalahan pada jenis kesalahan prosedural sebesar $10,8 \%$, kesalahan pada mengorganisasikan data sebesar 9,17\%, kesalahan pada pemanfaatan simbol sebesar $10 \%$, kesalahan pada melakukan manipulasi secara matematis sebesar $14,2 \%$, dan kesalahan pada menarik kesimpulan sebesar 10\%. Dapat disimpulkan bahwa keselahan terbesar adalah pada jenis kesalahan melakukan manipulasi secara matematis.

Setelah dilakukan analisis data terhadap seluruh jawaban siswa yang telah diperiksa, diperoleh hasil: 


\section{Soal nomor 1}

Terdapat $41,2 \%$ atau 14 orang siswa yang melakukan kesalahan dalam menjawab soal tentang mencari panjang jari-jari kubah masjid. Rincian siswa yang melakukan kesalahan yaitu 2 orang siswa dari kelompok bawah dan 1 orang siswa dari kelompok sedang masih melakukan kesalahan dalam jenis kesalahan prosedural mencari jari-jari sebiah kubah masjid. Berikutnya terdapat 2 orang siswa dari kelompok bawah melakukan kesalahan dalam jenis kesalahan mengorganisasikan data, 1 orang siswa kelompok bawah dan 1 orang siswa dari kelompok sedang melakukan kesalahan dalam jenis kesalahan mengurutkan, 2 orang siswa kelompok sedang melakukan kesalahan dalam jenis kesalahan pemanfaatan simbol, 2 orang siswa kelompok bawah dan 1 orang siswa kelompok sedang melakukan kesalahan dalam jenis kesalahan melakukan manipulasi data secara matematis, 1 orang siswa kelompok sedang dan 1 orang siswa kelompok atas melakukan kesalahan dalam jenis kesalahan menarik kesimpulan.

\section{Soal nomor 2}

Terdapat $47 \%$ atau 16 orang siswa yang melakukan kesalahan dalam menjawab soal tentang mencari panjang jari-jari kubah masjid. Rincian siswa yang melakukan kesalahan yaitu 2 orang siswa dari kelompok bawah dan 1 orang siswa dari kelompok sedang masih melakukan kesalahan dalam jenis kesalahan prosedural mencari jari-jari sebuah kubah masjid. Berikutnya terdapat 1 orang siswa dari kelompok bawah melakukan kesalahan dalam jenis kesalahan mengorganisasikan data, 1 orang siswa kelompok bawah dan 2 orang siswa dari kelompok sedang melakukan kesalahan dalam jenis kesalahan mengurutkan, 1 orang siswa kelompok sedang melakukan kesalahan dalam jenis kesalahan pemanfaatan simbol, 1 orang siswa kelompok bawah dan 1 orang siswa kelompok sedang melakukan kesalahan dalam jenis kesalahan melakukan manipulasi data secara matematis, 1 orang siswa kelompok bawah dan 3 orang siswa kelompok sedang melakukan kesalahan dalam jenis kesalahan menarik kesimpulan.

\section{Soal nomor 3}

Terdapat 52,9\% atau 18 orang siswa yang melakukan kesalahan dalam menjawab soal tentang mencari panjang jari-jari kubah masjid. Rincian siswa yang melakukan kesalahan yaitu 2 orang siswa dari kelompok bawah dan 2 orang siswa dari kelompok sedang masih melakukan kesalahan dalam jenis kesalahan prosedural mencari jari-jari sebiah kubah masjid. Berikutnya terdapat 2 orang siswa dari kelompok bawah melakukan kesalahan dalam jenis kesalahan mengorganisasikan data, 2 orang siswa kelompok bawah dan 1 orang siswa dari kelompok sedang melakukan kesalahan dalam jenis kesalahan mengurutkan, 1 orang siswa kelompok sedang melakukan kesalahan dalam jenis kesalahan pemanfaatan simbol, 2 orang siswa kelompok bawah dan 1 orang siswa kelompok sedang melakukan kesalahan dalam jenis kesalahan melakukan manipulasi data secara matematis, 2 orang siswa kelompok sedang dan 1 orang siswa kelompok atas melakukan kesalahan dalam jenis kesalahan menarik kesimpulan.

\section{Soal nomor 4}

Terdapat $76,5 \%$ atau 26 orang siswa yang melakukan kesalahan dalam menjawab soal tentang mencari panjang jari-jari kubah masjid. Rincian siswa yang melakukan kesalahan yaitu 2 orang siswa dari kelompok bawah dan 1 orang siswa dari kelompok sedang masih melakukan kesalahan dalam jenis kesalahan prosedural mencari jari-jari sebiah kubah masjid. Berikutnya terdapat 2 orang siswa dari kelompok bawah melakukan kesalahan dalam jenis kesalahan mengorganisasikan data, 3 orang siswa kelompok bawah dan 2 orang siswa dari kelompok sedang melakukan kesalahan dalam jenis kesalahan mengurutkan, 3 orang siswa kelompok sedang melakukan kesalahan dalam jenis kesalahan pemanfaatan simbol, 5 orang siswa kelompok bawah dan 1 orang siswa kelompok sedang dan 1 siswa kelompok atas melakukan kesalahan dalam jenis kesalahan melakukan manipulasi data secara matematis, 2 orang siswa kelompok bawah 1 orang siswa kelompok sedang dan 1 orang siswa kelompok 
atas melakukan kesalahan dalam jenis kesalahan menarik kesimpulan.

Untuk mengetahui penyebab kesalahan yang dilkukan siswa, dilakukan wawancara terhadap beberapa siswa yang kesalahannya berbeda. Berdasarkan hasil wawancara tersebut diperoleh faktor penyebab siswa melakukan kesalahan, yaitu sebagai berikut:

1. penyebab siswa melakukan kesalahan prosedural:

a. lupa harus dari mana mulainya

b. lupa rumus yang harus dipakai, tertukar antara rumus luas tabung dan volume tabung

c. kebiasaan siswa suka mengahapal prosedur mengisi jawaban, siswa tidak paham pengerjaan soal yang sebenarnya.

2. penyebab siswa melakukan kesalahan mengorganisasikan data

a. kurang lengkap dalam mengisi data

b. kurang paham tentang soal

3. penyebab siswa melakukan kesalahan mengurutkan

a. kurang paham dari mana urutan yang benar

b. tidak fokus pengerjaannya

4. penyebab siswa melakukan kesalahan pemanfaatan simbol

a. lupa simbol apa yang harus dipakai

b. suka meremehkan simbol satuan luas dan volume

c. tidak mengetahui satuan luas dan volume

5. penyebab siswa melakukan kesalahan melakukan manipulasi secara matematika

a. tidak mngetahui alasan untuk memanipulasi

b. kurang paham redaksi soal

c. tidak tahu apa yang ditanyakan dalam soal

d. bingung dalam perhitungan

6. penyebab siswa melakukan kesalahan menarik kesimpulan

a. kurang teliti dalam menjawab soal

b. meremehkan langkah menarik kesimpulan

c. menganggap gurunya yang harus mengerti jawaban siswa

d. berharap guru memberi keringanan

\section{SIMPULAN DAN SARAN}

Simpulan

1. Jenis kesalahan siswa

Kesalahan-kesalahan yang sudah dijelaskan dalam tahap hasil dan pembahasan adalah kesalahan-kesalahan yang dilakukan oleh siswa melalaui pengerjaan soal dan dilengkapi dengan wawancara. Kebanyakan kesalahan yang dilakukan siswa dalam mengerjakan soal bangun ruang sisi lengkung adalah kesalahan prosedural, kesalahan memanipulasi data secara matematik, kesalahan dalam pemanfaatan simbol, dan kesalahan menarik kesimpulan.

2. Persentase jenis kesalahan siswa

a. Kesalahan prosedur yang dilakukan siswa dalam mengerjakan soal tentang bangun ruang sisi lengkung yaitu sebesar $10,8 \%$

b. Kesalahan mengorganisasikan yang dilakukan siswa dalam mengerjakan soal tentang bangun ruang sisi lengkung yaitu sebesar $9,17 \%$

c. Kesalahan mengurutkan yang dilakukan siswa dalam mengerjakan soal tentang bangun ruang sisi lengkung yaitu sebesar $10 \%$

d. Kesalahan pemanfaatan simbol yang dilakukan siswa dalam mengerjakan soal tentang bangun ruang sisi lengkung yaitu sebesar 7,5\%

e. Kesalahan melakukan manipulasi secara matematis yang dilakukan siswa dalam mengerjakan soal tentang bangun ruang sisi lengkung yaitu sebesar $14,2 \%$

f. Kesalahan menarik kesimpulan yang dilakukan siswa dalam mengerjakan soal tentang bangun ruang sisi lengkung yaitu sebesar $10 \%$

3. Persentase banyaknya siswa yang melakukan kesalahan pada tiap soal

a. Banyaknya siswa yang melakukan kesalahan pada soal nomor 1 yaitu sebesar 41,2\% dengan kategori tinggi.

b. Banyaknya siswa yang melakukan kesalahan pada soal nomor 2 yaitu sebesar $47 \%$ dengan kategori tinggi. 
ISSN 2541-0660 @ 2017

c. Banyaknya siswa yang melakukan kesalahan pada soal nomor 3 yaitu sebesar 52\% dengan kategori tinggi.

d. Banyaknya siswa yang melakukan kesalahan pada soal nomor 4 yaitu sebesar 76,5\% dengan kategori sangat tinggi.

4. Penyebab kesalahan siswa dari semua jenis kesalahan yang dilakukan oleh siswa adalah sebagai berikut:

a. siswa lupa harus dari mana mulainya

b. lupa rumus yang harus dipakai, tertukar antara rumus luas tabung dan volume tabung

c. kebiasaan siswa suka mengahapal prosedur mengisi jawaban, siswa tidak paham pengerjaan soal yang sebenarnya.

d. kurang lengkap dalam mengisi data

e. kurang paham tentang soal

f. kurang paham dari mana urutan yang benar

g. tidak fokus pengerjaannya

h. lupa simbol apa yang harus dipakai

i. suka meremehkan simbol satuan luas dan volume

j. tidak mengetahui satuan luas dan volume

k. tidak mngetahui alasan untuk memanipulasi

1. kurang paham redaksi soal

m. tidak tahu apa yang ditanyakan dalam soal

$\mathrm{n}$. bingung dalam perhitungan

o. kurang teliti dalam menjawab soal

p. meremehkan langkah menarik kesimpulan

q. menganggap gurunya yang harus mengerti jawaban siswa

r. berharap guru memberi keringanan

\section{Saran}

Bagi siswa yang melakukan kesalahan prosedural disarankan untuk lebih memahami materi terkait bangun ruang sisi lengkung dan memperhatikan proses penyelesaian soalnya serta disarankan untuk tidak menghapal langkah-langkah pengerjaannya, karena proses hapalan kurang bermakna apalagi terkait konsep; yang lebih penting siswa harus banyak berlatih menyelesaikan soal-soal terkait materi bangun ruang sisi lengkung;

Bagi siswa yang melakukan kesalahan mengorganisasikan data disarankan siswa lebih mencermati soal-soal yang dihadapi, harus mengetahui mana yang yang ditanyakan dan mana yang diketahui;

Bagi siswa yang melakukan kesalahan mengurutkan disarankan untuk mencermati langkah pengurutan yang dicontohkan oleh guru;

Bagi siswa yang melakukan kesalahan pemanfaatan simbol disarankan siswa terlebih dahulu belajar tentang satuan, karena materi bangun ruang sisi lengkung, maka guru lebih menekankan pada penggunaan satuan luas dan volume serta konversi dari satuan ke satuan yang lainnya;

Bagi siswa yang melakukan kesalahan melakukan manipulasi secara matematis disarankan siswa lebih mengerti terkait perhitungan;

Bagi siswa yang melakukan kesalahan menarik kesimpulan disarankan siswa lebih teliti dan lebih memahami soal, agar mudah dalam menarik kesimpulan yang tepat dari setiap soal.

\section{DAFTAR RUJUKAN}

Ali, M. (1999). Pendidikan Bagi Anak Berkesulitan Belajar. Jakarta: Rineka Cipta.

BSNP. (2006). Standar Isi untuk Satuan Pendidikan Dasar dan Menengah. Jakarta: BSNP.

Buchori, M. (2000) Pendidikan Antisipatoris. Yogyakarta: Kanisius

Depdiknas. (2006). Kurikulum Tingkat Satuan Pendidikan (KTSP). Jakarta: Depdiknas

Soedjadi, R. (2000). Kiat Pendidikan Matematika Indonesia. Jakarta: Direktorat Jenderal Pendidikan.

Turmudi. (2008). Landasan Filsafat dan teori pembelajaran

Matematika

(Berparadigma Eksploratif dan Investigatif). Jakarta: Leuser Cipta Pustaka.

(2009). Taktik dan strategi Pembelajaran Matematika (Referensi untuk Guru SMK, Mahasiswa, dan Umum). Jakarta: Leuser Cipta Pustaka. 